\title{
Digitalization as Vector of Increasing Competitiveness the Agricultural Sector of Ukraine
}

\author{
Andrii Skrylnyk, Vira Chevhanova, Oleksandr Khadartsev, Svitlana Kulakova
}

\begin{abstract}
Current trends in the development of agricultural business are analyzed and modern factors affecting their competitiveness are investigated in the article. Scope of the implementation of digitalization processes in enterprises of the agricultural sector of Ukraine and author's assessment of their impact on competitiveness is considered. The prospects of increasing the economic efficiency and competitiveness of agricultural enterprises in modern conditions of operation are investigated. The naivety of investment resources in agricultural enterprises and the possibility of attracting them to digitalization projects are estimated the article. It is proved that economic processes digitalization in the agricultural sector of Ukraine will create unique opportunities for ensuring the internal balance of the consumer market, increasing the stability of rural areas and increasing the competitiveness of representatives of small agricultural businesses in Ukraine at the international level.
\end{abstract}

Keywords: digitalization, development, innovation, agricultural products, advantages, competitiveness.

\section{INTRODUCTION}

The growth in global agricultural trade is one of the current trends and strategic objectives of most countries the economy. Over the past decades, not only the structure of trade and the methods of marketing promotion agricultural products on international markets have changed, there has been an increase in the share of high-quality finished products in world exports [1].

The modern realities of globalization processes indicate that the ability to overcome socio-economic problems depends on the potential capabilities of the domestic agricultural industry to adapt to new world innovative forms, methods and tools of growing and selling products. So domestic agriculture faces new challenges: to master new innovative technologies for digitalization of economic processes in the agricultural sector, to adopt a new system of world values and production quality, to achieve European standards for sustainable development, to provide a basis for inclusive development of employment processes and the

Revised Version Manuscript Received on October 15, 2019.

Andrii Skrylnyk*, Department of Enterprise Economics and Human Resource Management, Poltava National Technical Yuri Kondratyuk University, Poltava, Ukraine.( Email: skrylnikas@gmail.com.)

Vira Chevhanova, Department of Enterprise Economics and Human Resource Management, Poltava National Technical Yuri Kondratyuk University, Poltava, Ukraine. (Email: chevganovavera@gmail.com.)

Oleksandr Khadartsev, Department of Enterprise Economics and Human Resource Management, Poltava National Technical Yuri Kondratyuk University, Poltava, Ukraine. (Email: alexkhadarcev@ukr.net.)

Svitlana Kulakova, Department of Enterprise Economics and Human Resource Management, Poltava National Technical Yuri Kondratyuk University, Poltava, Ukraine. (Email: slcveta@gmail.com.) redistribution of public goods [2, 3].

The implementation of these tasks is in the field of an innovative approach to managing economic processes in the agro-industrial sector and is the main challenge and prospect for Ukraine in achieving "Industry 4.0". Today, domestic agricultural enterprises need to change their approach to introducing the latest technologies into production and concentrate all available investment resources in this direction [4]. The share of the digital economy in the GDP of advanced countries until 2030 will reach 50-60\%., in Ukraine, this figure can be at $65 \%$, provided that the economic processes of the agricultural complex are digitalized, provides agricultural producers and processors with real opportunities to increase profitability and reduce operating costs.

Digitalization of economic processes in the agricultural sector of Ukraine will create unique opportunities for enabling internal balance of the consumer market, increasing the stability of rural areas and increasing the competitiveness of the agricultural business environment of Ukraine at the international level [9].

Significant contribution to the study of the development and increase of competitiveness and economic efficiency of agricultural enterprises was made by such scientists as: V. Andreichuk, A. Ermakov, P. Sabluk and others [1, 6]. However, today a number of issues remain insufficiently studied, in particular: problems and prospects for strengthening the competitive position of domestic agrarian in the context of digitalization of economic processes.

The purpose of the article is to study current trends in the development of agricultural enterprises and factors that will affect increase in the competitiveness of their activities in modern conditions of digitalization of agribusiness.

\section{RESULT AND DISCUSSION}

Agricultural enterprises functioning during a period of growing competition in international markets is determined by the complexity of the interconnections between economic processes within the industry and is difficult to predict for Ukraine. The state of the markets and the competitive environment of agricultural enterprises are changing dynamically, which requires them to constantly seek additional competitive advantages. Modern conditions for the functioning of agricultural enterprises are associated with 
constant changes in the external political and economic environment, which leads to the existence of numerous threats to functioning, which is especially dangerous when Ukraine is in the World Trade Organization, an increase in competitors in the domestic and international markets [6].

The situation that has developed in the country's agricultural production over two decades is characterized by the following indicators. The powerful climatic and labor potential for agricultural production in Ukraine is fully used. The potential ability of the Ukrainian lands to food security ranges from 150 to 500 million people. At the same time, gross agricultural output is now reaching 1990 levels. Regarding personnel potential, the people quantity indicator employed in agriculture is dynamic. There is a decrease in people quantity employed in this industry, which is an objective process. So, if in 1990, $17.1 \%$ were employed in agriculture, in 2000, those employed in this field account for $21 \%$ of the total quantity of employees, then already in 2018 $14 \%$. Over a ten-year period, the quantity employees decreased by $28 \%[1,8]$. The shortage of labor is associated with the general negative demographic situation and the uneven distribution of labor resources in the country, as a result there is a need not only for the movement of labor, but for its redistribution between sectors, which would ensure the most efficient functioning of the national economy $[8,11]$.

Development trends of agricultural enterprises indicator have shown that it is necessary to take into account a number of factors for the formation of competitiveness in a promising context: global technological changes in the processes of production and marketing of agricultural products in the food markets of the world; support of innovative initiatives of domestic agricultural enterprises; the formation of a long-term marketing strategy that will enable balancing domestic consumer markets and will stimulate the representatives of the agricultural business to innovative development.

The main global trend today is Industry 4.0 is the next phase of the digitalization of the economy, where the main role is played by Big Data analytics, predicative analytics, etc. Against the background of the Ukrainian IT market general development during recent years, Ukrainian developers have been paying more and more attention to such a popular area as the development of agricultural innovations [6].

Figure 1 shows the scope of the implementation of digitalization processes at enterprises of the agricultural sector of Ukraine and an author's assessment of the possibility of their implementation over 5 years. This study is based on qualitative observation of managers of agricultural enterprises of Ukraine by the authors of a scientific article [12].

Digitalization will form a plateau of competitive advantages for Ukrainian agricultural enterprises:

- high level of competitiveness;

- simplification of work with an array of information;

- cost savings;

- customer loyalty and demand stability;

- increase the image of the enterprise.

The introduction of technologies for the digitalization of economic processes by agrarian enterprises creates a competitive advantage in the context of operational processes, particular: increasing the level of transparency and the ability to timely make a management decision, instant exchange of information between competent employees, conducting market research and creating systematic approaches to responding to crisis situations.

In the draft State Target Program for the Development of the Agrarian Sector of Ukraine until 2020, special emphasis is focused on the introduction of technologies and innovations in this area. To increase the competitiveness of agricultural producers, the following activities are planned [5]:

- improving energy efficiency and energy saving by modernizing production and introducing the latest technologies;

- introduction of energy-saving technologies for the deep processing of agricultural products in the food and processing industries;

- agricultural production technical modernization stimulation.

Today in Ukraine there are about 200 new innovative projects in the field of agronomy and about 30 of them have already become successful companies with their own customer based both in Ukraine and abroad. Among them are Kray Technologies, GrainTrack, eFarmer, Skok Agro, BIOsens, SmartEP, UAbe. Despite the fact that Ukraine now urgently needs to increase the efficiency of agriculture, the development of innovations in the agricultural sector is financially stimulated not by Ukrainian, but by foreign investors.

The Ukrainian business environment of the agro-industrial sector is attractive to foreign investors. In 2018 powerful global manufacturers and investment companies attracted at least 1 billion dollars to the Ukrainian economy. Financial resources international organizations to used for projects of digitalization and robotization of processes of growing, storing and exporting grain crops, melons, plant protection products, dairy products, production of agricultural equipment (investment companies Salic (Saudi Arabia), Kadorr Group, Bayer German concern, Japanese "Sumitomo concern").

To list the areas of digitalization proves that have already taken a prominent place in the agricultural sector of Ukraine: accounting processes, work with personnel, setting tasks that are issued for production, automation of supplies and logistics. But robotization in the agriculture of Ukraine has not yet developed; rather simple functions rely on robots like washing, cleaning warehouses and the others. Although this is a stable global trend already in livestock business: in Germany and France today up to $35 \%$ of milk-producing equipment is work, in Denmark - more than 50\%, the Netherlands $-60 \%[10]$.

Despite the numerous declarations on digitalization, Ukrainian agricultural holdings invest very little in the development of agricultural technologies. And when in the world today, advanced agricultural business companies introduce artificial intelligence and robots into operational processes, Ukrainian companies still continue introducing 
GPS trackers, basic accounting programs, video monitoring, receiving data from sensors and, in the best case, electronic document management [9].

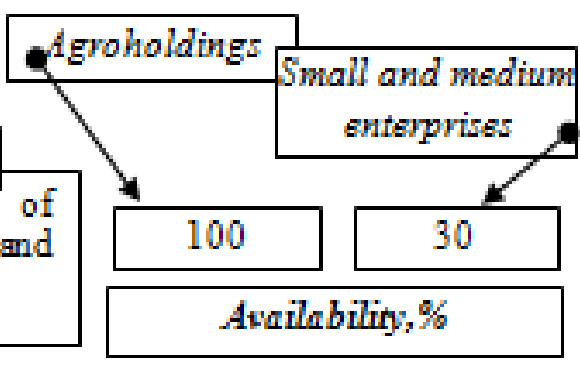

\section{Digital relief and online maps}

during the cultivation of the land, the cultivation of crops and the harvest the importance of the spatial mapping factor is increasing Therefore, the application of modem electronic mapping solutions is crucial in this area and helps to solve many problems of agricultural companies

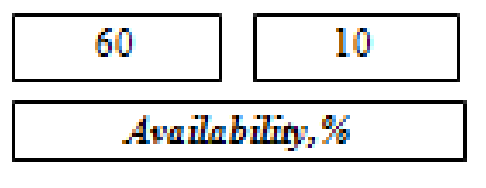

Creating Online Plafforms
inchudes blockchain-based anctions and smart contracts, antomation
of customs clearance and clearance, online analysis and price
comparison, automation of counterparty resource exchange to
preventilliquidaccumulation.

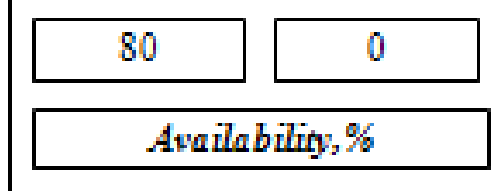

Automation of industrial production and processes
Smart - Enterprise technologes provide accurate feedmg,
microclimate control, health information collection, weight mobility;
forming a network of smart fields for which fertilizers and plant
protection product are introduced by drones, vertical fams and
more.

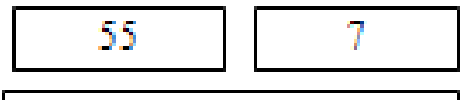

Availability, $\%$

Agrobiotechnology and innovation in the final product
solutions that increase crop yrelds and INestock productivity. Y1eds
can be enhanced by genetics and soil microbiolog, imnovations in
plant protection, reduced exposure to hamful factors, production of
organic and mineral fertilizers

Energy efficiency and waste conbol
agribusiness is one of the few that can not only consume energy but
also provide resources for altemative sources. It is important to
recycle production waste into biofuels, to reduce emissions into the
atmosphere and to introduce the most environmentally friendly
packaging.

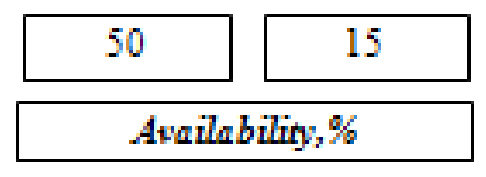

Figure 1. Spheres influence of digitalization processes on the agricultural sector

In Ukraine, the technologies that quickly pay off are still the most popular - within two years. This is land bank accounting, remote control of fuel in tanks of mobile equipment, agrochemical analysis of the soil. At the same time, modern technological solutions that have a longer payback period (within 5-7 years) are not implemented.

Ukraine has every opportunity to turn into a large center of agrarian innovations, particular: developed agriculture; highly qualified IT-specialists; the cultivation of most crops that are listed on world exchanges (this means that the innovative product that will be developed in Ukraine will be in demand by farmers all over the world) the low level of regulated activity of scientific and research companies compared to the EU, USA and Australia [11].

Digitalization can lead to certain changes in the structure of agricultural production in Ukraine and the monopolization of agricultural markets. The reason for this is the limited financial capacity of small farms and the lack of skill in attracting resources from technical assistance projects of the EU and the USA. On the other hand, it is necessary to understand that digitalization creates conditions for the 
sustainable development of small farms, because it can facilitate their access to sales markets, for example, using blockchain technologies, as well as reduce the bureaucratic burden and the associated cost of time and money as in terms of reporting to authorities, and in terms of obtaining new knowledge, communication with suppliers, consultants and the like. Figure 2 displays the digitalization vectors of the agricultural sector of Ukraine and the assessment of the simplicity investment resources in agricultural enterprises and the possibility of involving them in digitalization projects.

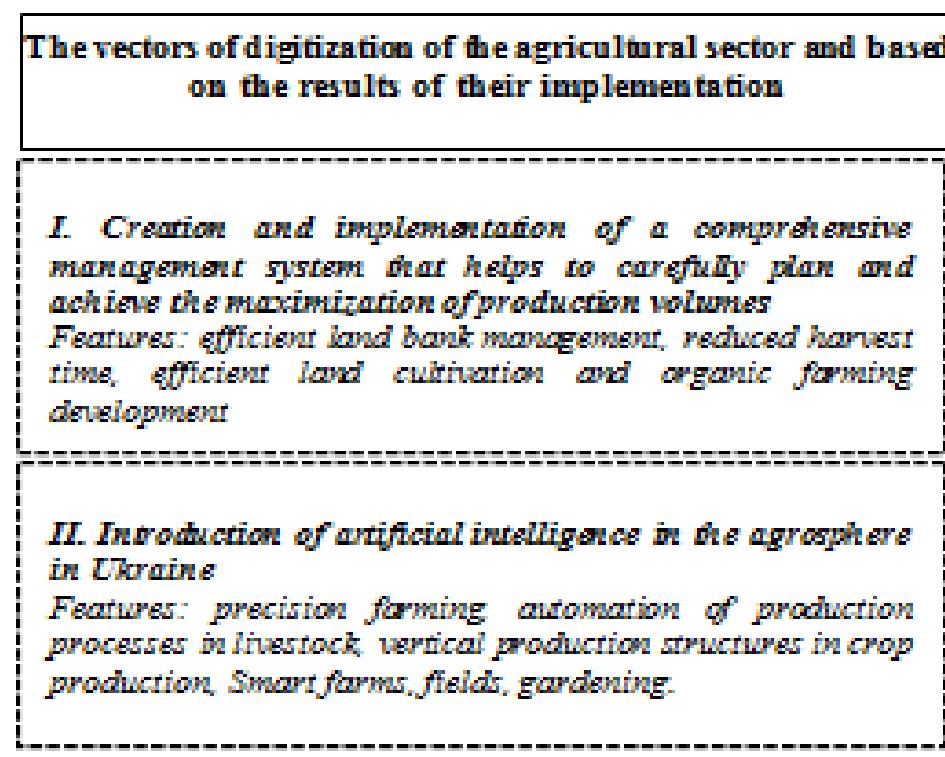

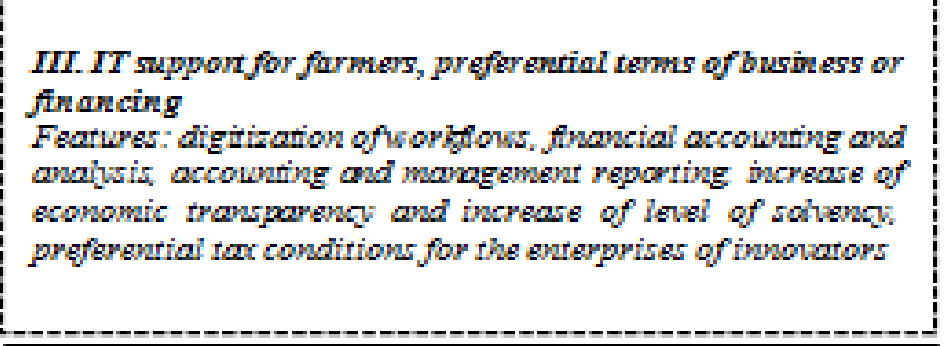

Figure 2. Digitalization vectors of the agricultural sector in Ukraine and possible investment resources for their

\section{Unmanned technolbgy, robotics of agribusiness \\ Features: Optimization of cost for soil analusis. differentiated fertiliter application, new technigues for soil treatment and fertilizer application minimitation of fluel and energy costs}

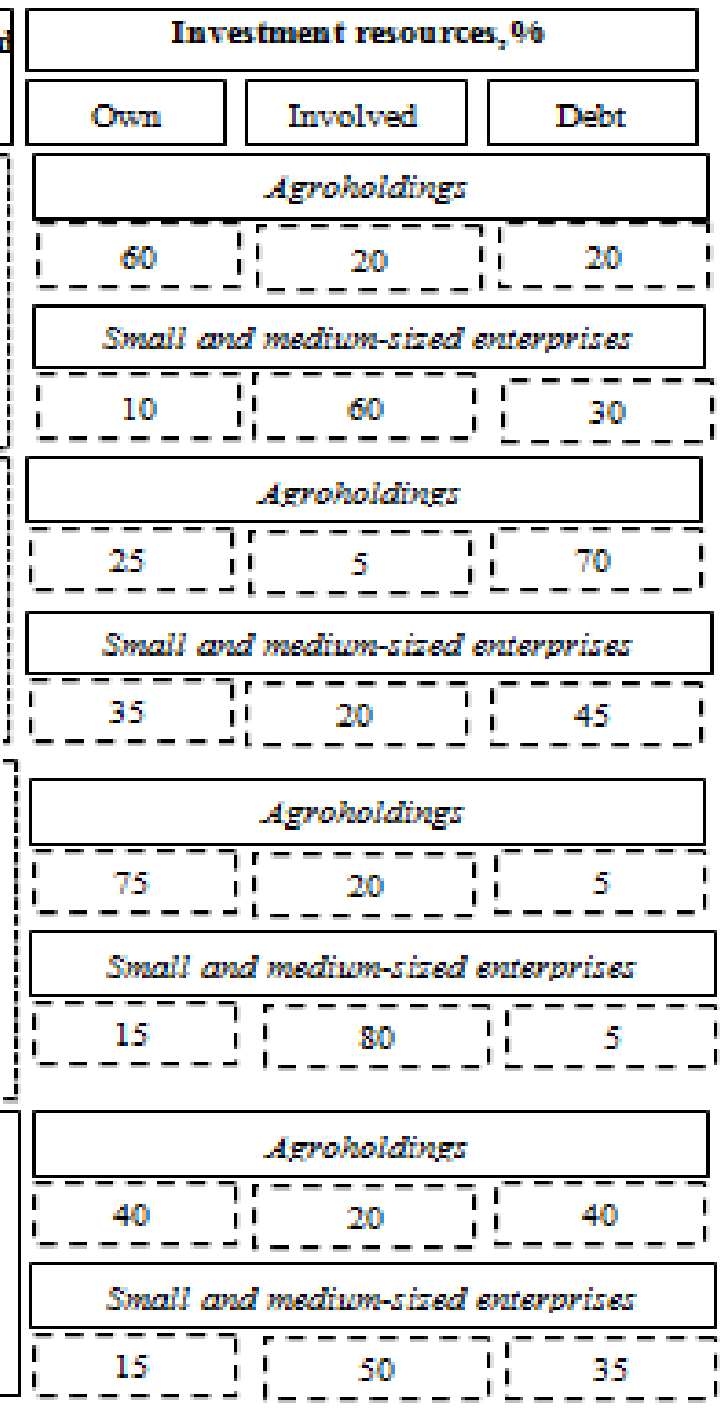

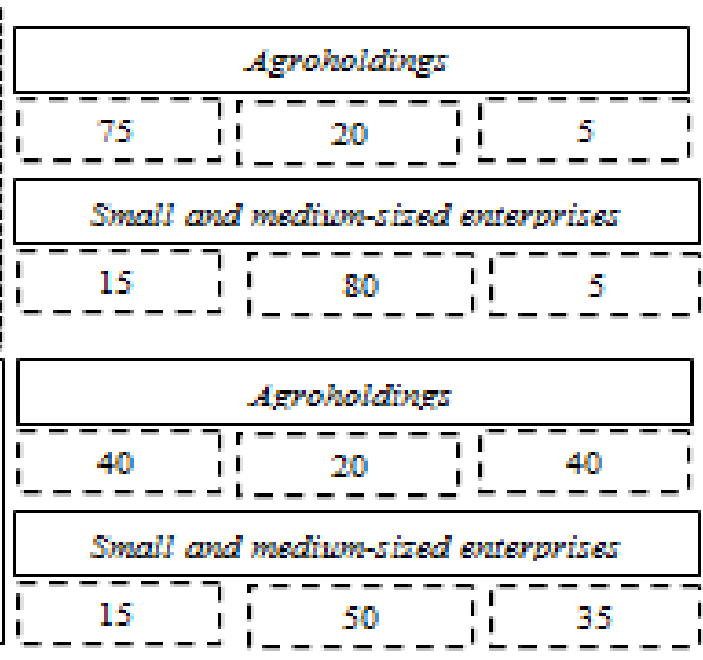

\section{implementation}

Based on the results of an expert assessment of the financial and economic status of domestic agricultural holdings (KERNEL, ASTARTA), representatives of small and medium-sized agribusiness, the authors of the article formed the most probable structure of investment resources that can form a project platform for the development of digitalization of the agricultural sector of Ukraine. It should be noted that today agricultural holdings in Ukraine have a sufficient supply of their own investment resources and a significant potential of attracted investment resources through the sale of securities. At the same time, representatives of small and medium agricultural businesses can only rely on grants (USIDO, GIZ, etc.) and financing of technical assistance projects of the European Union.

Today, pressure from the world community on the agricultural sector of Ukraine is growing rapidly. According, it is necessary to implement solutions that will enable

agribusiness enterprises both to increase productivity and at the same time reduce the burden on resources and the environment. In this context, digital transformation offers great prospects, because recently it has become increasingly difficult for small farmers to compete with large ones in carrying out tasks such as caring for the environment, manufacturing high-quality products, and implementing social programs.

For many countries, the digital transformation of the agricultural sector has been a huge step forward. In European countries, due to the fact that all farmers are in more or less the same conditions, agricultural cooperation is successfully operating. In Ukraine, the processes of cooperation of small and medium agricultural enterprises in many regions of Ukraine are not activated. The reason for this is a rather high

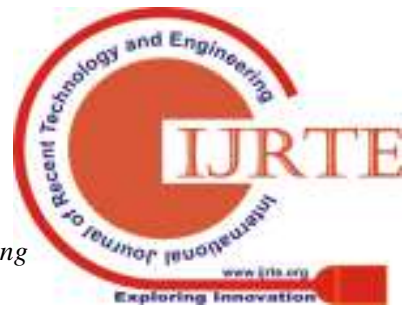


level of the shadow economy of small and medium agricultural enterprises. At the same time, the digitalization of business processes at small and medium agricultural enterprises of Ukraine will affect not only an increase in the level of transparency of their work, but in the synthesis with cooperation processes, will significantly increase the level of competitiveness on international markets.

\section{CONCLUSION}

The interaction between the IT sector and the agricultural sector in Ukraine is expanding and has practical results. Domestic agribusiness moves to digital footing in process optimization, accounting, contract work, resource management, quality control, planning, forecasting. Digitalization and robotization point projects are implemented mainly in crop production.

The main goal of the digitalization processes of representatives agribusiness of Ukraine is to optimize costs: reduce the amount of plant protection products; have point injection or drone, robotic ground vehicles and mechanisms. In the future, for 5-6 years, according to the authors of the article, Ukraine will carry out an innovative transformation of the agricultural sector to $40 \%$ of fixed assets and $75 \%$ of intangible assets, while the rates of market and innovative transformation will be set by agricultural holdings.

Ukrainian large agribusiness companies are interested in using integrated software solutions for doing business and digitizing operational activities, as this is a single path to sustainable development and competitiveness in world markets. Given the rather high payback of digital agribusiness technologies in Ukraine, representatives of small and medium agribusiness do not have obvious investment resources for their implementation. Therefore, to increase their competitiveness, it is necessary to develop a number of regional programs of technical and financial assistance for the implementation of digitalization projects, and the removal of project payback periods up to 3 years. The authors of the article note that the deeper the digitalization technologies will penetrate into the agribusiness of Ukraine, the more detailed should be the staff retraining program, both at the individual company level and at the regional level. It will make it possible to preserve the personnel potential of agricultural companies and balance regional labor markets.

\section{REFERENCES}

1. G. O. Young, "Synthetic structure of industrial plastics (Book style with paper title and editor)," in Plastics, 2nd ed. vol. 3, J. Peters, Ed. New York: McGraw-Hill, 1964, pp. 15-64.Hudz O. (2018) "Tsyfrova ekonomika: zmina tsinnostey ta oriyentyriv upravlinnya pidpryyemstvamy", [Digital economy: changing the values and benchmarks of enterprise management], Ekonomika. Menedzhment. Biznes, № 2 (24), pp 4-12

2. Kraus N. M., Klaus K. M. (2017) Innovatsiyne tablo Ukrayiny. Skhidna Yevropa: ekonomika, biznes ta upravlinnya. [Innovative scoreboard of Ukraine. Eastern Europe: Economics, Business and Management], available at: http://www.easterneuropeebm.in.ua/6-2017-ukr

3. Rohrbeck R., Thom N., Arnold H. (2015) IT tools for foresight: The integrated insight and response system of Deutsche Telekom Innovation Laboratories.
Technological Forecasting and Social Change. Vol. 97. P. 115-126.

4. Yurchak O.V. (2018) "Industriia 4.0 - scho tse take ta navischo tse Ukraini". Association of Industrial Automation Enterprises of Ukraine, [Online] available at: https://appau.org.ua/publications/industriya-4-0-shho-tsetake-ta-navishho-tse-ukrayini/ (Accessed 24 March 2018).

5. Rozporyadzhennya Kabinetu Ministriv Ukrayiny «Pro kontseptsiyu rozvytku tsyfrovoyi ekonomiky ta suspil'stva Ukrayiny na 2018-2020 roky» (2018), [Online], available at: https://www.kmu.gov.ua/ua/npas/pro-shvalennyakoncepc iyi-rozvitku-cifrovoyi-ekonomiki-ta-suspilstva-ukrayinina-20182020-roki-ta-zatverdzhennya-planu-zahodivshod o-yiyi-realizaciyi

6. Kutsmus N. (2015) "Methodological peculiarities of rural economy research from neoruralism standpoint" Baltic Journal of economical studies, Vol. 1 (2), pp. 69-76.

7. Levkivs'ka L.(2015) "Formuvannia ta funktsionuvannia intehrovanykh struktur $\mathrm{v}$ ahrobiznesi" Formation of market economy, Vol. 33., pp. 234-242.

8. Borodina O. Prokop I., Popova O. (2015) "Polityka sil's'koho rozvytku na bazi hromad v Ukraini" [Community Based Rural Development Policy in Ukraine], scientific report, State Institution "Institute of Economics and Forecasting NAS of Ukraine". Kyiv, Ukraine.

9. De Clerck J.-P. (2017) "Digitization, digitalization and digital transformation: the differences", I-Scoop, [Online] available https://www.i-scoop.eu/digitization-digitalization-digitaltransformation-disruption/ (Accessed 05 May 2017).

10. Koptelov A. K. (2017) "Digitization (otsyfrovka) vs Digitalization (tsyfrovyzatsyia)" [Online] available at: http://koptelov.info/digitization-digitalization/ (Accessed: 05 May 2017).

11. Honoré T. (2018) "Dydzhytalyzatsyia - ne moda, a sposob razvytyia byznesa", Columbus [Online] available at https://www.columbusglobal.com/ru/blog/didzhitalizaciy a-sposob-razvitiya-biznesa (Accessed: 22 August 2018).

12. Baker Tilly News (2017) "5 korysnykh tekhnolohij dlia fermeriv ta silhosppidpryiemstv" [Online] available at: http://www.bakertilly.ua/news/id1152. (Accessed: 28 March 2017)

\section{AUTHORS PROFILE}

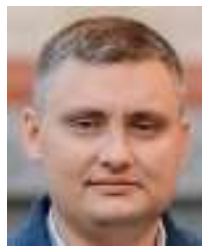

Andrii Skrylnyk, graduated 2000-2005 Poltava National Technical Yuri Kondratyuk University, Ukraine, Economist, Master degree at "Enterprise Economy" Specialty. 2012-2014 - State High Education Establishement «Donetsk National Technical University», Ukraine, postgraduate study In 2014 defended the thesis under «Economics and Enterprise Management: under the types of business activity» specialty, $\mathrm{PhD}$. Has 13 yrs of scientific and pedagogical experience. Develops and teaches Master's courses. An author of 40 scientific articles, (including 17 devoted to the problems of managing the investment activity and SME development based on implementation of international and European experience.), 5 collective monographs, 5 textbooks, 2 of them published abroad. Participant in three international scientific conferences on developing and implementing the projects on development of business, territorial units and urban social environment Took part scientific GIZ projects executed at the costs of international organizations. Since 2016 and till now - an Expert of GIZ project "Integrated Urban Development in Ukraine" (Poltava)

ORCID ID: 0000-0001-9622-4217 


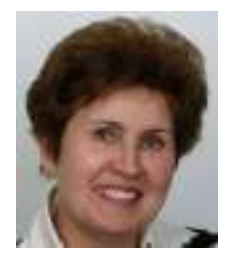

Vira Chevhanova, graduated 1973-1977 - Poltava Engineering-Construction Institute, Ukraine, Construction-Engineer, «Industrial and civil construction» specialty. 1979-1983 - Moscow Institute of Management named after S. Ordzhonikidze, Candidate of Sciences (Economics), "Economics, National economy planning and management (construction) specialty" 2011- National Academy of Sciences of Ukraine, State Institution "Institute of Economics and Forecasting", training under 0502 "Management". 2014 - Professor of the Department of Enterprise Economy and Personnel Management.. Has 37 yrs. of experience in scientific and teaching activity. Candidate of Economic Sciences, Professor, Candidate's thesis on "National Economy, organization, management and planning (construction field)" specialty. An experienced manager, 22 years of being in charge of the department. Applies modern methods of teaching, develops and teaches Master's courses. An author of 8 textbooks, recommended for use in higher educational institutions of Ukraine and abroad; 176 scientific articles, 6 monographs. Advisor of three candidate's theses. The outcomes of scientific research in integrated urban development: 2 monographs, 16 scientific works, manager of 3 research projects carried out at the expense of international organizations (2013, 2016 and 2017). Expert of the GIZ project «Integrated Urban Development in Ukraine» (Poltava) since 2016 and till now.

\section{ORCID ID: 0000-0003-1428-430X}

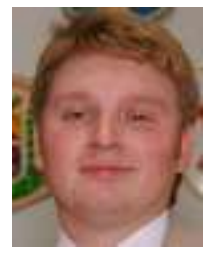

Oleksandr Khadartsev, graduated 1998-2003 Poltava National Technical Yuri Kondratyuk University, Ukraine, Economist, Master degree at "Enterprise Economy" Specialty. 2005-2008 - Poltava National Technical Yuri Kondratyuk University, Ukraine, postgraduate study. Has 14 yrs. experience of scientific and educational work. In 2017 defended his Ph.D. thesis in National Economy and Management, Ph.D. in Economy. Develops and teaches advanced Masters courses. An author of 50 scientific articles, (including 19 devoted to the problems of economic development of administrative-territorial units), 3 collective monographs, 3 textbooks. A participant of the scientific conferences. Took part in scientific GIZ projects executed at the costs of international organizations (2013, 2016, and 2017). Since 2016 and till now - an Expert of GIZ project "Integrated Urban Development in Ukraine" (Poltava)

ORCID ID: 0000-0002-3520-4164

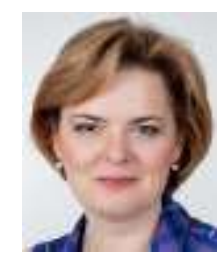

Svitlana Kulakova, graduated 1995-2000 - Poltava National Technical Yuri Kondratyuk University, Ukraine, Economist, Master degree at "Enterprise Economy" Specialty. 2005-2008 - Poltava National Technical Yuri Kondratyuk University, Ukraine, postgraduate study. Has 17 yrs. experience of scientific and educational work. In 2012 defended her Ph.D. thesis in Economics. An experienced lecturer, applies modern teaching methods, develops and teaches Master's courses, does scientific researches constantly, advances her competence level permanently. Passed international training and took part in international research and practice Forum "Innovation in science: call of contemporaneity", Bulgaria, Varna Free University "Chernorizets Hrabar". Results of her R\&D work concerning demography, labor economy, social economy and politics.

ORCID ID: 0000-0002-7149-0356 